\title{
Correction to: Assessing recall bias and measurement error in high-frequency social data collection for human-environment research
}

\author{
Andrew Bell ${ }^{1}$ (D) $\cdot$ Patrick Ward $^{2,3} \cdot$ Md. Ehsanul Haque Tamal ${ }^{4,5} \cdot$ Mary Killilea $^{1}$ \\ Published online: 28 February 2019 \\ (C) Springer Nature B.V. 2019
}

\section{Correction to: Population and Environment https://doi.org/10.1007/s11111-019-0314-1}

The original version of this article unfortunately contained a mistake. The name of "Md. Ehsanul Haque Tamal" is now corrected in the author group of this article. The original article has been corrected.

Publisher's note Springer Nature remains neutral with regard to jurisdictional claims in published maps and institutional affiliations.

The online version of the original article can be found at https://doi.org/10.1007/s11111-019-0314-1

Andrew Bell

andrew.reid.bell@nyu.edu

1 Department of Environmental Studies, New York University, 285 Mercer St., New York, NY 10003, USA

2 Master of Environmental Policy Program, Duke Kunshan University, No. 8 Duke Avenue, Kunshan, Jiangsu 215316, China

3 International Food Policy Research Institute (IFPRI), 1201 Eye St, NW, Washington, DC 20005-3915, USA

4 icddr,b, 68, Shaheed Tajuddin Ahmed Sarani, Mohakhali, Dhaka 1212, Bangladesh

5 International Food Policy Research Institute (IFPRI), Dhaka Office, House 10A, Road 35, Gulshan 2, Dhaka 1212, Bangladesh 